\title{
On the Distributional Implications of Social Protection Reforms in Latin America
}

\section{Armando Barrientos*}

November 2011

\begin{abstract}
The paper tracks recent changes in the components of social protection in Latin America, the reforms to social insurance in the 1990s and the growth of social assistance in the 2000s, and assesses their effects on poverty and inequality and implications for welfare institutions in the region. The analysis focuses on public subsidies to social protection and their rebalancing. The paper concludes that the expansion of social assistance in the region will result in social protection institutions which are more comprehensive and distributionally progressive.
\end{abstract}

Keywords: Latin America, social insurance, social assistance, social protection, poverty, inequality

JEL classification: I31, I38, O54

Copyright (C) UNU-WIDER 2011

* Brooks World Poverty Institute, University of Manchester, UK, e-mail: Armando.Barrientos@manchester.ac.uk

This study has been prepared within the UNU-WIDER project 'The New Policy Model, Inequality and Poverty in Latin America: Evidence from the Last Decade and Prospects for the Future', directed by Giovanni Andrea Cornia.

UNU-WIDER acknowledges the financial contributions to the research programme by the governments of Denmark (Ministry of Foreign Affairs), Finland (Ministry for Foreign Affairs), Sweden (Swedish International Development Cooperation Agency_Sida) and the United Kingdom (Department for International Development). 


\section{Acknowledgements}

The author would like to thank Giovanni Andrea Cornia, Kenneth Roberts, and the contributors to the UNU-WIDER project on 'The New Policy Model, Inequality and Poverty in Latin America' for helpful comments that have greatly improved this paper. The errors that remain are the author's alone.

The World Institute for Development Economics Research (WIDER) was established by the United Nations University (UNU) as its first research and training centre and started work in Helsinki, Finland in 1985. The Institute undertakes applied research and policy analysis on structural changes affecting the developing and transitional economies, provides a forum for the advocacy of policies leading to robust, equitable and environmentally sustainable growth, and promotes capacity strengthening and training in the field of economic and social policy making. Work is carried out by staff researchers and visiting scholars in Helsinki and through networks of collaborating scholars and institutions around the world.

www.wider.unu.edu publications@wider.unu.edu

UNU World Institute for Development Economics Research (UNU-WIDER)

Katajanokanlaituri 6 B, 00160 Helsinki, Finland

Typescript prepared by Janis Vehmaan-Kreula at UNU-WIDER

The views expressed in this publication are those of the author(s). Publication does not imply endorsement by the Institute or the United Nations University, nor by the programme/project sponsors, of any of the views expressed. 


\section{Introduction}

Social protection reforms in Latin America over the last two decades can be described, using football terminology, as a game of two halves. The 1990s were dominated by reforms to social insurance funds, with a majority of countries replacing pay-as-you-go defined contribution schemes with individual retirement accounts and the rest relying on changes to the parameters of pension schemes (Mesa-Lago 2007). The 2000s have been dominated by the rapid expansion of antipoverty programmes, human development conditional income transfer programmes, non-contributory pensions, and child and family transfers (Barrientos and Santibañez 2009b). This study tracks the shift in policy focus and examines the implications for poverty and inequality, and for the future of social protection institutions, in the region.

The reforms of social insurance funds in Latin America1 in the 1990s have been subject to detailed examination. They came part of a liberalization reform package introduced under structural adjustment programmes in the region. Pension reforms acquired flagship status as the World Bank became a strong advocate of Chilean-style individual retirement accounts managed by private providers. Individual retirement accounts chimed with several features of the liberalization orthodoxy: individual choice, an increasing role of the private sector, financial management, and flexible labour markets. In the hype, it was easy to lose sight of the fact that the core objective of the reforms was to reduce budget deficits and the size of the state. Looking back, it is remarkable that the distributional implications of the reforms attracted very little attention.

The 2000s have been dominated by the expansion of social assistance. 2 In policy terms, the shift in focus to social assistance makes a lot of sense. In the year 2000, one in every two workers in the region relied on informal employment, and only one in every four workers made regular contributions to a pension fund (ILO 2001). In Latin America, social protection has been described as truncated, because it reaches mainly groups in formal employment (Barrientos 2004; Fiszbein 2005). The reform of social insurance funds, even if successful beyond expectations, could affect at best a minority of the labour force and their dependants. Social insurance and social insurance reforms bypassed a majority of the labour force and population in the region taken as a whole. The expansion of social assistance is intended to reach those sectors in the population excluded from social insurance. Social assistance programmes contribute to fill in the gaps in truncated social protection systems in the region.

From the perspective of social protection systems in the region, the focus on social assistance in the 2000s is of great significance. The political conditions needed to facilitate this shift are challenging. Social assistance was highly residual and intensely

1 The study focuses on 18 countries, i.e. all the South American countries (except for the Guyanas) and all the Central American countries. Caribbean countries are largely excluded except for the Dominican Republic.

2 Social assistance comprises tax-financed programmes and policies addressing poverty and vulnerability; whereas social insurance includes contribution or premium based institutions providing coverage against life course and work related contingencies. Together with labour market policies, whether 'passive' or 'active', social insurance and social assistance make up social protection. Social protection together with programmes and policies providing basic services, health, education and housing for example, constitute social policy. 
politicized. 3 Direct income transfers to households in poverty had long been associated with short-term measures from populist incumbents aimed at aligning support before an election. The derogatory term asistencialismo was commonly used to describe these practices. Political support for social assistance was conspicuous by its absence. The rapid growth of social assistance programmes in Latin America signals an important shift within political and policy discussions. Antipoverty transfer programmes are widely credited with having contributed to downward trends in poverty in the region, maintained through the recent financial crisis, and to the reversal of rising inequality trends (Cornia 2010; López-Calva and Lustig 2010; World Bank 2010). Social protection, and especially antipoverty policy, has risen to the top of the political and policy agenda. Lula's re-election in 2006 is credited by many to his success with Bolsa Família. It is not surprising that emerging left of centre governments in Latin America pay attention to poverty and inequality, given their natural support base and ideology. It is unusual that right of centre governments, like Fox in Mexico or Piñera in Chile, single out social protection as a priority area of policy and felt the need to commit themselves to the expansion of existing antipoverty programmes.

The study provides an account of this policy shift, Sections 2 and 3 discuss in turn social insurance reforms and the expansion of social assistance, but it is particularly concerned with two key questions. What are the distributional implications of these reforms? The paper traces the implications of these changes for poverty and inequality in the region, and in Section 4 makes a case for focusing attention on public subsidies to social insurance and assistance as means of assessing the distributional effects of social protection systems. What does this shift in policy focus tell about the future of social protection systems in the region? Section 5 considers the reformed social protection institutions in the context of Latin America open economies and left governing coalitions. A final section draws out the main conclusions.

\section{Social insurance reforms in the 1990s}

A handful of Latin American countries began to implement social insurance funds in the 1920s with other countries following suit in the second half of the century (Mesa-Lago 1991). Social insurance funds followed the Southern European model, collecting contributions from workers and their employers into a fund which covered old age, disability pensions and, in some countries, health insurance. Over time, governments consolidated the various occupational funds into larger pay-as-you-go pension funds and used the accumulated savings. The transition from Bismarckian occupational contributory social insurance funds to Beveridgean state supported social insurance enabled governments to reward workers in the public sector and industry and sustain the political coalitions supporting import-substitution strategies. In Southern Cone countries, and especially Uruguay and Argentina, governments were able to extend coverage to broader sections of the labour force. The evolution of these social insurance schemes varied across countries in the region, but by the 1990s, most schemes had become heavily dependent on government support to plug in growing deficits. Structural adjustment programmes implemented in the region incorporated pension reforms as a means to stem growing public sector deficits and enhance financial and labour market liberalization.

3 Prior to the 1988 Constitution in Brazil, government responsibility for social assistance was limited to contributing financially to charitable institutions, often faith based (Jaccoud et al. 2009). 


\subsection{Social insurance reforms}

Following Chile's 1981 pioneering pension reform, pension reform was implemented in Peru in 1993, Argentina and Colombia in 1994, Uruguay in 1996, Mexico and Bolivia in 1997, El Salvador in 1998, Costa Rica in 2001 and the Dominican Republic in 2003. Enabling legislation was approved in Venezuela but was never implemented. The reforms share common traits. They replaced, fully or partially, unfunded social insurance pension schemes with individual retirement accounts, managed by private providers. In the new pension environment, employees in formal employment are required to contribute a fraction of their earnings to a retirement account. Pension fund managers compete for savings, manage workers' accounts, invest the pension fund, and surrender balances at retirement. They also provide disability and survivor benefits. At retirement, workers use their retirement account balances to make pension arrangements, which include purchasing an annuity from insurance providers or agreeing a scheduled withdrawal of the balances from their pension accounts.

Resistance to the reforms led to diverse outcomes; see Figure 1. In Chile, Bolivia, Mexico, El Salvador, and the Dominican Republic, individual retirement plans replaced pay as you go pension schemes in full. Governments absorbed the liabilities associated with the old pension plans and the costs of the transition to the new plans. In Colombia and Costa Rica, defined benefit pay-as-you-go schemes and defined contribution individual retirement pension plans operate side by side. In Argentina, the two types of pension plans also operate side by side, but with a first pillar pay-as-you-go pension scheme. In Costa Rica and Uruguay, the two types of pension plans have each a dedicated pillar. 4

Brazil was included in the Figure as an example of a country which did not embark on structural reforms but implemented instead parametric reforms (Pinheiro 2005).

\subsection{Distributional effects of social insurance reforms}

The main objective of pension reforms was to reduce public subsidies to social insurance and therefore fiscal deficits. Introducing individual retirement plans with a direct link between contributions and benefits for individual workers raised the expectation that public subsidies would no longer be required (Gill et al. 2004). One area in which the reforms had explicit distributional implications was in the provision of minimum pensions. Even here, the distributional channels were minimized. Some countries, like Peru, did not include a minimum pension in the reformed pension plans. Other countries, like Chile and Argentina, included a minimum pension guarantee but restricted entitlements to workers with unfeasible long contribution records (20 years in Chile, 30 years in Argentina). Colombia was the only country to introduce a limited redistributive component to their minimum pension. The limited provision of minimum pensions meant that coverage of low income groups remained the responsibility of the government through non-contributory pension schemes and social assistance (Barrientos 1998).

4 Argentina 'nationalized' individual retirement accounts in 2008 (Mesa-Lago 2009). 
Figure 1: Pension reform in Latin America

Before the reforms

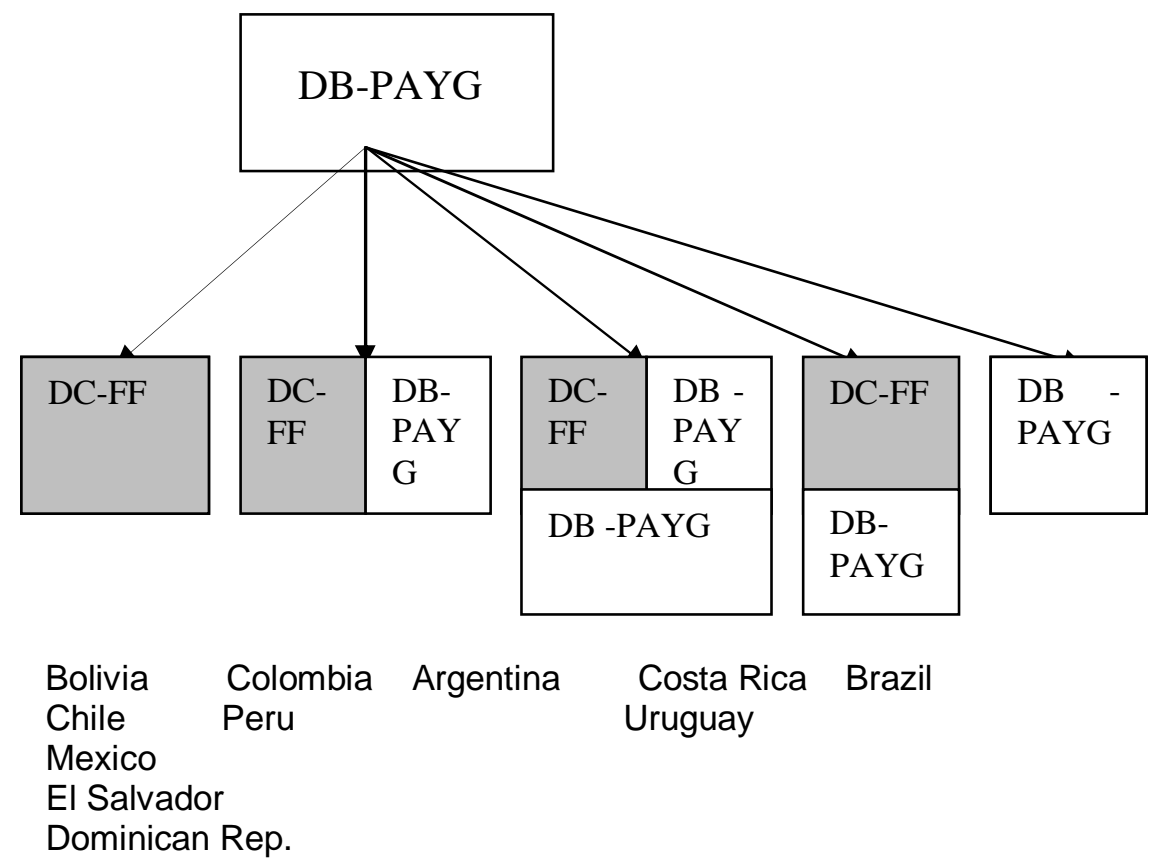

DB-PAYG is Defined benefit - Pay as you go;

DC-FF is Defined contribution - Fully funded

Source: Author.

On paper, social insurance reforms were supposed to have limited distributional effects. In practice, the mounting costs of the transition, the costs associated with maintaining deficit pay-as-you-go schemes where these remained in place, and the growing costs of preventing old age poverty through non-contributory pensions, all have some distributional effects. In fact, pension reform has resulted in rising public subsidies to social insurance. Chile is a good case in point. The public subsidies associated with the pension reform were 3.8 per cent in 1981, at the start of the reforms. They rose to 5.4 per cent in 1990 and 6 per cent in 2000, and were predicted to remain at around 4 per cent in 2010 (Arenas de Mesa 2005). 5 The bulk of the deficit is associated with the transition costs of the reforms. Public subsidies to finance non-contributory pension are around one tenth of the public subsidies to the supposedly private individual retirement accounts. The reform of social insurance in Chile did not achieve a reduction in public subsidies to social insurance, but the opposite. 6

5 These estimates do not include an additional 1.3 per cent of GDP required to finance the pension plan of the military and police.

6 In 2008 the Chilean government introduced a solidarity pension which is intended to replace the then existing non-contributory pension programme PASIS, and also provide partial transfers to low-income older pensioners. 


\section{Social assistance expansion in the 2000s}

From the turn of the century, there has been an observable shift in the priority given to the extension of social assistance programmes by governments in the region. Large scale direct income transfer programmes focused on poor and poorest households have been introduced in the majority of countries in the region. The earlier programmes, Mexico's Progresa/Oportunidades and Brazil's Bolsa Escola/Bolsa Família now reach around a quarter of all households, while Ecuador's Bono de Desarrollo Humano reaches about 40 per cent of all households. 7 Human development income transfer programmes have dominated attention from international policy makers, who branded them as conditional cash transfers or CCTs. In fact there is considerable diversity in the design of antipoverty transfer programmes in Latin America. There is also an expansion of non-contributory pension programmes in the region, a more traditional form of social assistance. More recently, child transfers have been reformed and extended in Uruguay and Argentina. Integrated antipoverty programmes like Uruguay's PANES and Chile's Chile Solidario illustrate yet a different approach (Barrientos 2010).

\subsection{Design and incidence}

A useful typology of social assistance programmes in developing countries distinguishes three 'ideal types'.8 Pure income transfer programmes provide direct transfers in cash to households in poverty. Non-contributory pensions are a good example of pure income transfers. Income transfers plus services combine income supplements with basic service provision or utilization. Human development conditional transfers, for example, provide direct income transfers to participating households linked to service utilization conditions, especially health care, schooling and nutrition. Integrated antipoverty programmes provide tailored transfers and preferential access to services covering a range of deficits and have a focus on reducing social exclusion. 9 These three ideal types are grounded on different understandings of the underlying causes of poverty: poverty as lack of income; poverty as multidimensional deficits; poverty as multidimensional deficits and social exclusion. What all these programmes have in common is that they are tax-financed interventions led by public agencies and addressing poverty and vulnerability, i.e. social assistance.

Large scale antipoverty programmes or social assistance have grown rapidly in all development regions in the last decade, especially in middle income countries. In a Latin American context, it is important to emphasize their focus on intergenerational poverty persistence (Barrientos and Santibañez 2009b). The programmes are often focused on households in extreme poverty, and have beneficiary selection procedures that take account of differences in poverty intensity. Antipoverty programmes are increasingly multidimensional in nature. They aim to address the cumulative effects of

7 Mexico's Progresa was first introduced in 1997/8 in selected rural areas. It was later extended nationwide as Oportunidades in 2003. Bolsa Escola in Brazil developed out of municipal initiatives in 1995, which received support and financing from the federal government in 1997 before becoming a federal programme in 2001, and together with other direct transfer programmes combined into Bolsa Familia in 2003.

8 Programme information is from the Social Assistance in Developing Countries database version 5 (Barrientos et al. 2010).

9 In integrated poverty programmes income transfers are not the main component. 
deficits in income, employment, education and health care, widely perceived to be the main factors explaining poverty persistence. The focus on children, and on regular and reliable transfers, is intended to maximize the impact of the programmes on poverty persistence. Figure 2 notes the incidence of human development conditional transfer programmes in the region. Across countries in the region these programmes have a combined reach of 12 per cent of the population (unweighted average) in circumstances where the population in extreme poverty was 12.9 per cent and the population in poverty 32.1 per cent (ECLAC 2009).

Figure 2: Reach of human developmet conditional transfers in Latin America

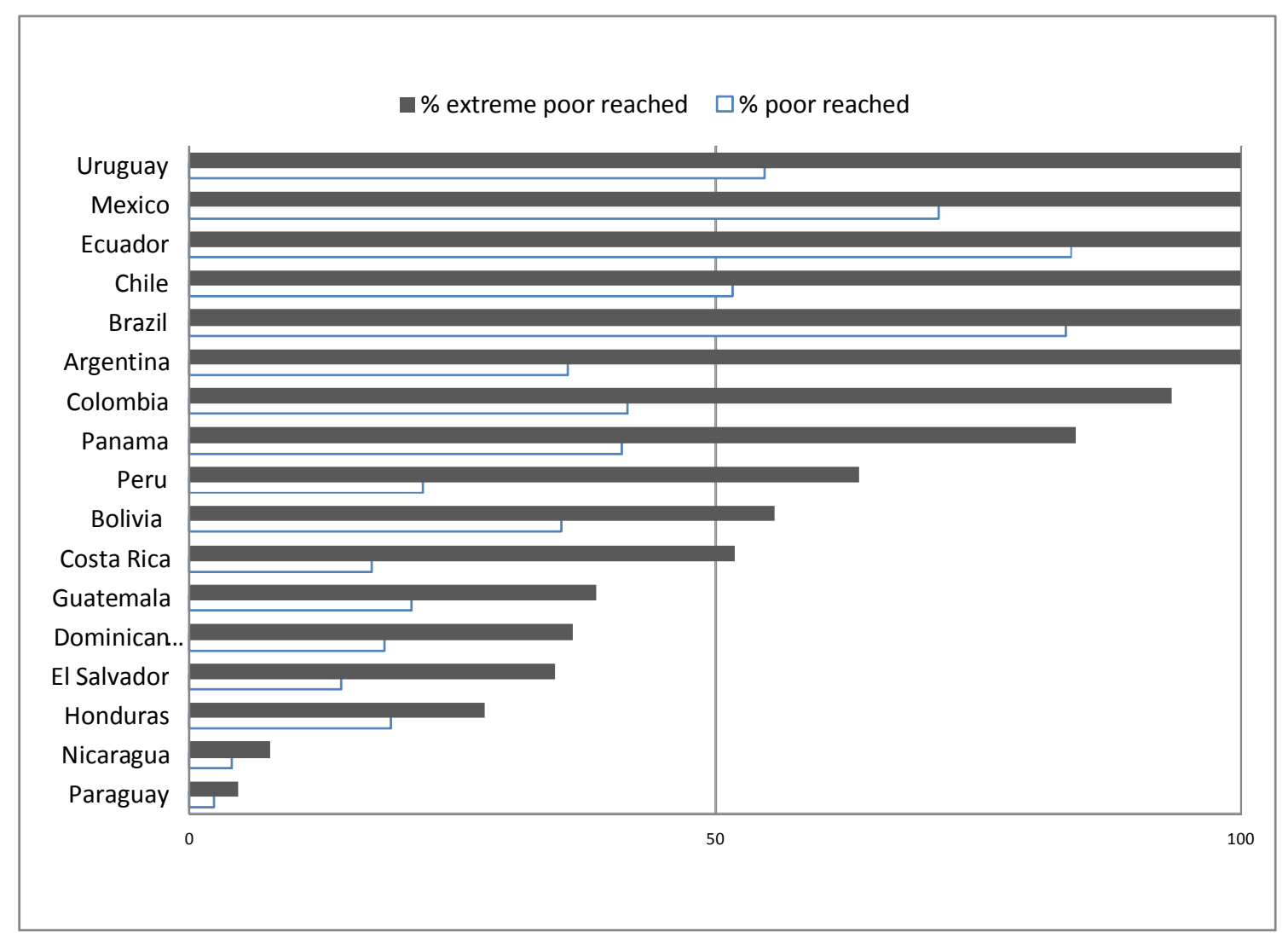

Source: ECLAC (2009) Social Panorama 2009.

\subsection{Low- and upper-middle-income countries}

The spread of social assistance has been slower and more difficult in lower middle income countries than in upper middle income countries (Barrientos and Santibañez 2009a). Lower income countries in the region face constraints in delivery capacity and financing which slow down the scaling up of antipoverty programmes (Soares and Britto 2007). The influence of donors in the design and implementation of these programmes has not been universally positive. In upper middle income countries, the main challenge has been the institutionalization of social assistance. Often antipoverty programmes have been introduced as short-term interventions, akin to development projects, as opposed to long-term institutions tasked with the reduction, prevention and eventual eradication of poverty. This is an important challenge which many countries are addressing through the establishment of ministries of social development, separate from ministries of labour and social protection which have traditionally managed social 
insurance institutions in the region. As will be discussed in more detail below, the integration of social assistance and social insurance is a particular challenge in the region.

\subsection{Why the growth in social assistance?}

The expansion of social assistance has been long overdue in Latin America, but its rapid growth in the 2000s must be explained in terms of changes in the political economy environment. The truncated nature of social insurance in Latin America matched the political coalitions which evolved from and sustained the import substitution industrialization development model, dominant in the post-Second World War period. The often unfunded, expansion of social insurance entitlements to workers in the burgeoning public sector and industry provided a channel through which the surpluses extracted from agriculture were redistributed to the emerging middle classes. 10 The export-led growth strategies which became dominant in the 1980s undermined these political coalitions, for example by restructuring public sector employment and by dismantling the protection from international competition available to industrial sectors. The diversity in institutional outcomes from social insurance reforms described in Figure 1 reflects the strength of the political coalitions behind import substitution strategies in resisting change, often in the context of restricted or suspended of democratic processes (Kay 1999).

The growth in social assistance has also coincided with the left turn in Latin American politics following the consolidation of democracy. Left of centre coalitions were expected to address the acute deficits in social protection which are the legacy of structural adjustment and dictatorship in Latin America, the deuda social. Expanding antipoverty programmes is an appropriate means of addressing poverty, social exclusion, and social cohesion-especially in a context in which governing coalitions find limited room to change macroeconomic or labour market policy. It is uncontroversial to posit a 'natural' affinity between left of centre governments and propoor policies, 11 but care must be taken not to overstate this point. In fact right of centre governments in Mexico (Fox), Colombia (Uribe), El Salvador (Saca), and more recently Chile (Piñera) have also supported antipoverty programmes. It is also the case that populist left of centre governments, Nicaragua (Ortega) and Venezuela (Chavez), have explicitly avoided making direct income transfers to households in poverty a cornerstone of their social protection policies. The influence of left of centre governments on the growth of social assistance in Latin America should not be overstated.

The perceived effectiveness of flagship human development conditional transfer programmes has been important in aligning public and political support in Brazil and Mexico (Lindert and Vinscensini 2008). This comes in no small part from their social investment orientation in programme design. Their main objective is not mitigating poverty but a more ambitious upgrade in the productive capacities of younger generations. Poverty research has demonstrated the multidimensional nature of deficits

10 This point was made by Huber who noted that social protection systems expanded the most in countries that followed import-substitution-industrialization policies (Huber 1996).

11 Cross-country studies on poverty find a link between left-of-centre governments and lower poverty rates (Birdsall et al. 2011; López-Calva and Lustig 2010; Pribble et al. 2005). 
faced by households in extreme poverty. It has also shaped policy tools to improve programme effectiveness, for example techniques to rank households in poverty and to evaluate programme impact and effectiveness. Improvements in beneficiary selection and in programme evaluation have contributed to bolster credibility among policy makers and the general public. The fact that social assistance budgets amount to a fraction of one per cent of GDP has not escaped the attention of policy makers and taxpayers. The emergent social assistance in Latin America is perceived as grounded in research, focused on social investment, and able to deliver poverty reduction outcomes.

\subsection{Distributional effects of social assistance}

The poverty reduction effectiveness of social assistance measures the extent to which a particular intervention can be attributed to a reduction in poverty among beneficiary households. In the context of antipoverty transfer programmes in developing countries, their impact on poverty is best captured by changes in the poverty gap and the poverty gap squared measures. Attributing a reduction in poverty to social assistance interventions requires that attention is paid to economic trends and behavioural responses to the transfers. Antipoverty programmes operate in inauspicious circumstances, often against a backdrop of structural transformation. They are focused on groups in extreme poverty facing a range of deprivation including limited access to employment and basic services. The effectiveness of antipoverty programmes is enhanced by economic growth and investment in basic services. It is often hard to disentangle the influence of different factors on measured poverty.

Figure 3 provides estimates of the poverty reduction effectiveness of Mexico's Progresa (Skoufias 2005). These provide perhaps the most accurate set of figures on the impact of social assistance on poverty because they compare poverty among households similarly eligible for participation in Progresa, but where one group joined at the start of the programme in 1997 and another group joined two years later in 1999. The assessment of impact therefore controls for environmental trends as well as behavioural responses. Using as a poverty line the 50th percentile of household consumption, Skoufias (2005) finds that Progresa had a very limited impact on the headcount poverty headcount rate, with a further 11.7 per cent of beneficiaries reaching the poverty line; but a stronger impact on the poverty gap and the poverty gap square. Progresa reduced the poverty gap among beneficiaries by more than one third compared to eligible but not yet participating individuals. It reduced the poverty gap squared by just over 45 per cent. These estimates confirm that Progresa had a stronger impact among the poorest beneficiaries.

Surprisingly, much less is known about the impact of social assistance on poverty than about its impact on inequality. 12 The impact of antipoverty programmes on inequality has been scrutinized closely in Brazil, where the longstanding rising trend in inequality appeared to have turned sharply about the turn of the century just when antipoverty programmes were being scaled up. Several studies have come to the conclusion that

12 ECLAC estimated the contribution to inequality of different types of transfers with household survey data circa 2008 for 18 Latin American countries (ECLAC 2009). Unfortunately, ECLAC lumped together social assistance with private transfers from civil society organizations and included noncontributory pensions as pension income, separate from social assistance. Their conclusion is that social assistance transfers, thus computed, have a very marginal but positive effect on inequality. 
Bolsa Família has made an important contribution to the reduction of inequality in Brazil (Barros et al. 2007; Soares et al. 2006; Soares et al. 2010; Soares et al. 2007).13

Figure 3: Difference in difference poverty estimates for a sample of Progresa eligible beneficiaries 1997-99

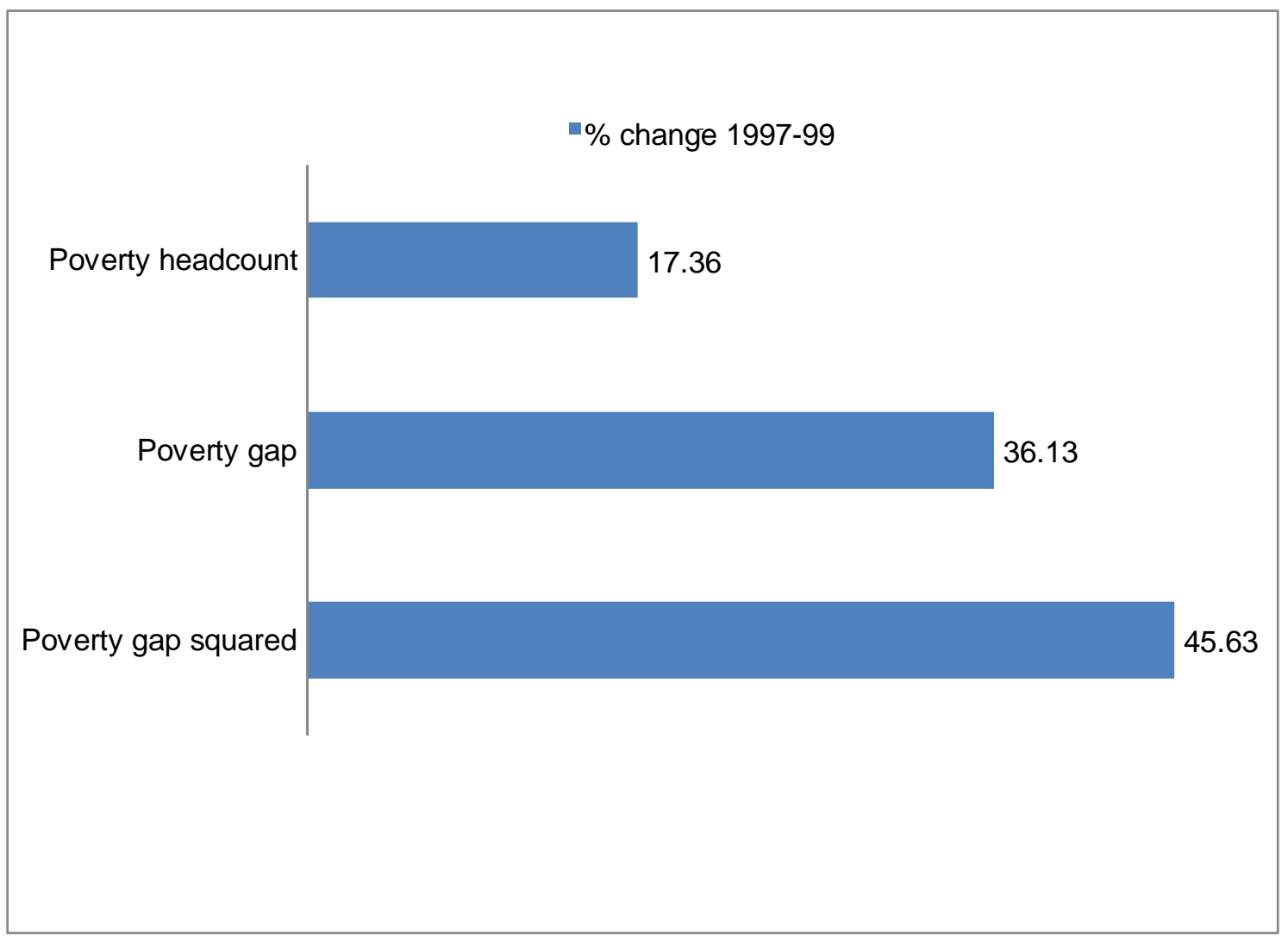

Notes: Poverty line is 50th percentile of per capita household consumption. Difference in difference (Dif2) is calculated by subtracting the change in measured poverty of the treated group from the change in the control group. \% change is calculated as: Dif $2 /$ measured poverty of the treatment group in 1997.

Source: Skoufias (2005).

The identification of the impact of Bolsa Família on inequality relies on factorial decomposition of the Gini coefficient into the contribution of the different income sources. Denoting G for the Gini; Ck for the concentration coefficients of income source $\mathrm{k}$; and $\mathrm{w}$ for the weight of each source in total income; the Gini of per capita household income is decomposed dynamically as (with the caps indicating the initial observation):

$$
\Delta G=\sum_{k}\left[\bar{w}_{k} \Delta C_{k}+\left(\bar{C}_{k}-\bar{G}\right) w_{k}\right]
$$

Table 1 summarizes data on Bolsa Família and on its effects on inequality reported in Soares et al. (2010). The contributions of two sources of income linked to social

13 Soares et al. (2007) extend this analysis to the impact of human development conditional transfer programmes in Mexico and Chile on inequality and find they had contributed to the fall in inequality between 1996-2003 in Chile and 1996-2004 in Mexico. 
assistance are reported in the table: basic pension income and Bolsa Família transfers. In the Brazilian social protection system, Beneficio de Prestaçāo Continuada is a noncontributory pension scheme for older and disabled people living in households in extreme poverty; Prêvidencia Social Rural is another non-contributory pension programme providing transfers to workers in informal employment in agriculture mining and fishing. They provide a pension equivalent to one minimum wage. Workers affiliated to contributory social insurance who fail to accumulate enough contributions at retirement also receive a minimum guaranteed pension of one minimum wage, which makes it difficult to identify these two groups with precision in the survey data. Reported pension income at one minimum wage in value covers all these types of transfers. The other income source selected is Bolsa Família transfers, although in practice this includes reported income from all direct transfer programmes. The decomposition indicated above finds that these two sources of income associated with social assistance appear to be responsible for 15 and 16 per cent respectively of the overall decline in the Gini in the period 1999-2009 (Soares et al. 2010). Social assistance transfers would have contributed around one third of the reduction in the Gini in Brazil over a decade.

Table 1: Estimated impact of Bolsa Família on Inequality (monetary values in $\mathrm{R} \$ 2009$; all figures estimated from PNAD)

\begin{tabular}{l|rrrrr}
\hline & 2001 & 2003 & 2005 & 2007 & 2009 \\
\hline Bolsa Família data from PNAD & & & & & \\
Beneficiaries millions & 9.7 & 27.4 & 31 & 33.1 & 41.2 \\
\% population & 5.8 & 16 & 17.2 & 18.1 & 22.2 \\
Beneficiaries mean income R\$ & 336 & 222 & 225 & 219 & 233 \\
Beneficiaries mean income less transfer & 328 & 212 & 211 & 202 & 212 \\
R\$ & & & & & \\
Mean transfer R\$ & 8 & 10 & 15 & 19 & 21 \\
\% of beneficiary income & 2.5 & 4.7 & 6.5 & 8.8 & 9.5 \\
& & & & & \\
Impact on inequality & $1999-01$ & $2001-03$ & $2003-05$ & $2005-07$ & $2007-9$ \\
Change in Gini attributed to basic pension & 0.094 & -0.387 & -0.126 & -0.236 & -0.123 \\
income = MW & & & & & \\
Change in Gini attributed to BF transfers & -0.081 & -0.208 & -0.116 & -0.106 & -0.212 \\
Change in overall Gini & 0.181 & -1.228 & -1.386 & -1.35 & -1.384 \\
\hline
\end{tabular}

Data source: (Soares et al. 2010).

Some caution must be exercised in interpreting these figures. The Bolsa Família budget stands at around 0.4 per cent of GDP, while the combined budgets of the noncontributory pension schemes are around 1.8 per cent of GDP, see Figure 3. The results above suggest that spending 0.4 per cent of GDP on Bolsa Família could have the effect of reducing the Gini by just less than one point. Soares et al. (2010) attribute the effectiveness of Bolsa Família in reducing inequality to the fact that it reaches extremely poor households. There are issues with data and methodology which need to be considered. The PNAD household surveys does not allow a direct identification of Bolsa Família beneficiaries, so identification is made by examining the amounts reported by potential beneficiaries, an approach widely agreed to be imperfect. 14 The

14 Soares et al. (2010) provide a detailed discussion of data and methodological issues. 
impact on inequality from the introduction of an antipoverty transfer programme is likely to be a one-off change. It is intriguing to see from the Table that Bolsa Família appears to have a cumulative effect on the Gini. This might have arisen from the expansion of Bolsa Família beneficiaries and/or from increases in the value of the transfers. The Table provides some confirmation of these; but concerns remain about the size of the changes in beneficiary numbers and in the value of transfers compared to the size of the effects on the Gini. 15 The factorial redistribution considers only the contribution of changes in income sources on inequality, but it is important to take on board the changes in policy which are responsible for the changes in income sources in the first place. In the case of Brazil, minimum wages are a fundamental policy lever because they set the value of social assistance benefits apart from Bolsa Família, but they are also a benchmark for informal workers' wage setting. During Lula's two administrations the minimum wage increased in real terms by over 50 per cent. This policy change had a impact on both labour earnings of low income workers, noncontributory pension benefits, and indirectly on Bolsa Família (Saboia 2009). Changes in labour earnings remain the single most important influence on inequality in Brazil, accounting for 59 per cent of the reduction in the Gini 1999-2009. As noted above the impact of pension benefits where the benefit is equivalent to a minimum wage accounted for a further 15 per cent of the fall in the Gini. The influence of the minimum wage on the decline in inequality is likely to be primal. Another issue recommending caution is that the estimation and decomposition of the Gini does not take account of the distributional impact of raising the revenue to finance social assistance. The implicit assumption is that fiscal revenues have no distributional effects. A more comprehensive perspective on this would require examining the combined effects of taxes and transfers. The handful of studies on this issue in Brazil suggest that the tax-transfer system generates very little redistribution (Immervoll et al. 2006; Silveira 2008).

\section{Rebalancing public subsidies to social insurance and assistance}

A productive way to bring together the discussion on the distributional effects of social insurance reforms and the growth of social assistance and link it to policy is to focus on the balance of public subsidies to social protection in Latin America. This approach acknowledges that in practice social insurance schemes in Latin America, whether 'public' pension schemes or 'private' individual retirement plans, absorb a significant amount of public subsidies. Social assistance, on the other hand is wholly financed through public subsidies. The point is to fix attention on the allocation of public subsidies. The expansion in social assistance in the region will inevitably involve a rebalancing of public subsidies to social insurance and social assistance.

The analysis above concluded that because the reach of social insurance is restricted to workers in formal employment, public subsidies to social insurance will have a limited impact on poverty and, depending on the revenue mix, adverse effects on inequality. The analysis of the distributional effects of social assistance, on the other hand, suggested that its impact on poverty is significant, but its impact on the distribution of income is limited. This is in line with the findings from an emerging literature studying the distributional effects of taxes and transfers in the region (De Castro et al. 2008; Scott

15 An alternative explanation is that antipoverty transfers might have more than proportionate effects on the productive capacity of households, and that these effects unfold over time (Barrientos, in press). This would be the case if transfers help beneficiaries overcome poverty traps, for example. 
2005; Skoufias et al. 2010). A rebalancing of public subsidies from social insurance to social assistance is bound to be welfare improving.

It is illustrative to consider the current situation in Brazil. Figure 3 shows the financing requirements as a proportion of GDP of the different components of the social protection system in Brazil in 2008.

The distribution of public subsidies within social protection is highly regressive. They include highly generous pension entitlements to civil servants to the tune of 2.35 per cent of GDP (Pinheiro 2005). The urban component of the private sector social insurance fund is close to break-even point, but there is considerable inequality in the distribution of entitlements within the fund. A majority of social insurance pensioners only manage to qualify for the minimum guarantee pension benefit equivalent to one minimum wage (Schwarzer and Querino 2002). The rural component which includes Prêvidencia Social Rural, a programme aimed at extending social insurance entitlements to workers in informal employment had a deficit of 1.29 per cent of GDP in 2008. The rural component of the private social insurance fund is best understood as noncontributory or partially-contributory. The two explicit social assistance components, Bolsa Família and the Beneficio de Prestaçao Continuada absorb just less than 1 per cent of GDP. Public subsidies are marginally tilted towards social insurance, but public subsidies per beneficiary are heavily biased towards privileged civil servants. As much as 2.35 per cent of GDP in public subsidies go to less than 1 million civil servants, while 0.38 per cent of GDP is shared by over 12 million Bolsa Família beneficiary households.

Consideration of the distributional effects of public subsidies to social insurance and social assistance would recommend a rebalancing away from social insurance and towards social assistance, as a means of maximizing the welfare effects of public transfers. In fact, the expansion of social assistance in the region in the 2000s indicates that this rebalancing is underway (Barrientos 2009). It is an explicit objective of government policy in several countries in the region, including Brazil, Mexico and Argentina (De Castro et al. 2008; Scott 2005). The rebalancing has been facilitated by a context of growth and rising fiscal revenues. The fact that social assistance programmes absorb a very small proportion of GDP has largely kept these changes at a low key. The substantial public subsidies to social insurance suggest that the scope for re-balancing these subsidies is large in upper middle income countries in the region (Barreix et al. 2007; Breceda et al. 2009; Cubero and Vladkova Hollar 2010; Goñi et al. 2008).

\section{Options for the future of social protection in open economies}

\subsection{Growing social insurance?}

Social insurance schemes in the region have consolidated after the bout of reforms in the 1990s. 16 Argentina's 'nationalization' of private pension funds in 2008 appears to indicate a different trend, but there are conflictive views on the motivation and sustainability of the changes. Individual retirement plans have emerged from the 2008 financial crisis with slightly fewer contributors, but the swift recovery has contributed to

16 This is not to ignore subsequent reforms to individual retirement plans in some countries (Bertranou et al. 2009). 
minimize the financial impact (Marcel and Tapia 2010). Trends in the density of contributions among workers affiliated to individual retirement accounts will need to be closely scrutinized in the future as they provide clues on the extent to which these plans will provide satisfactory levels of retirement income for current contributors.

There are few indications that, absent growing public subsidies, social insurance institutions in the region are capable of reaching groups currently excluded. Efforts to 'grow' social insurance have been heavily dependent on the government support. Brazil's Prêvidencia Social Rural represents an important attempt to incorporate informal workers in rural areas within social insurance institutions. The strategy adopted was to adjust the requisites for entitlement to take account of the specific nature of rural employment. A lower contributory requirement of 10 years was granted to informal workers, and its implementation was suspended for ten years to provide incentives for workers to join and start contributing. In practice, the contributory requirement was never introduced, and the benefits are financed largely through government subsidies. Chile's introduction of the Pilar Solidario in 2008 provides a guaranteed floor to pension income, through a mix of non-contributory benefits and subsidies to contributory benefits. Argentina's Plan de Inclusion Previsional effectively lowered the conditions for accessing benefits for self-employed workers and other workers excluded from social insurance. Uruguay's and Argentina's child subsidy programmes fill in the gaps in pre-existing child subsidy programmes restricted to workers in social insurance funds and tax credits for high income groups.

There is some common ground in these examples. They are limited to upper middle income countries with relatively high social insurance coverage (in the context of Latin America). They are all financed in full from public revenues. There are no crosssubsidies from social insurance contributors. They were all explicitly developed and implemented as a response to the perceived deficiencies of social insurance schemes, and as a means to sustain them. Are they a case of governments trying to find effective ways of supporting the inclusion of low income and vulnerable workers within social insurance? Or are they a case of public funds being employed to cover social insurance's 'bad risks'? The absence of cross-subsidies from social insurance suggests that the latter interpretation might be closer to the truth.

\subsection{Social protection after the growth of social assistance}

There are strong arguments supporting the view that social protection systems in the region have been strengthened by the growth of social assistance in the last decade. Social assistance helps to extend social protection coverage to sections of the population traditionally excluded from social insurance institutions, and is effective in reducing extreme and persistent poverty. It also has the potential to improve human development and economic inclusion among low income groups. Social assistance absorbs a very small fraction of public revenues, and there is every prospect that social assistance budgets will reduce in the future as poverty reduces. The growth in social assistance is a welcomed development because it fills in a missing component from social protection systems in the region.

On the other side of the balance sheet, social assistance is effective in reducing poverty only as part of a successful development strategy which includes economic growth and the provision of basic services. Antipoverty programmes of the type currently in place 
Figure 4: Brazil's social protection: financing requirement and transfers 2008/9

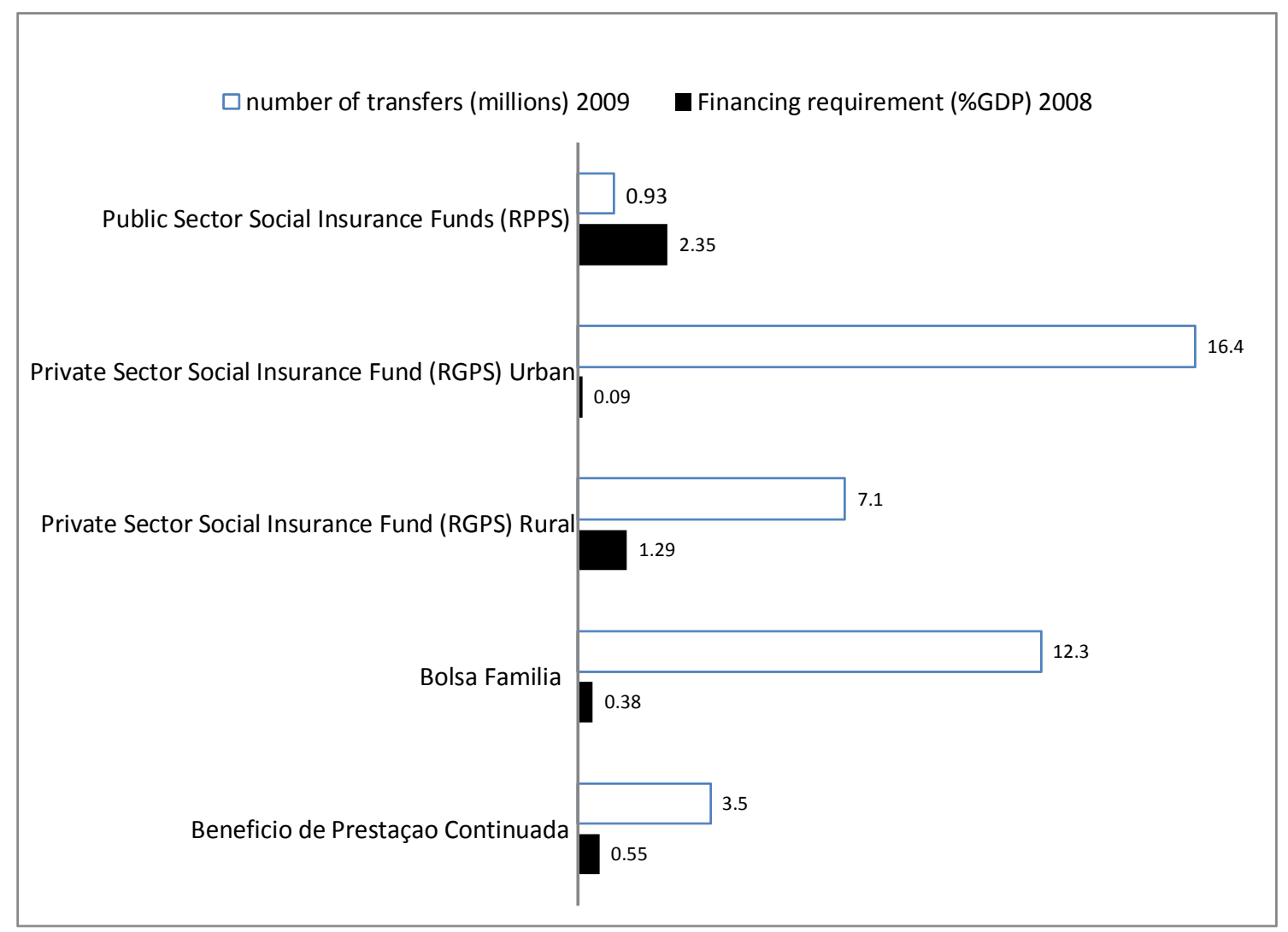

Source: Own calculations from data in Mesquita (2010).

in Latin American countries have more limited impact on poverty in contexts of low growth and acute deficits in service infrastructure. The spread and effectiveness of social assistance in lower middle income countries in the region have been limited compared to upper middle income countries. Social assistance in these countries has not reached the scale required to make a strong contribution to the reduction of poverty and vulnerability, and there are large deficits in their institutionalization. Social insurance is also much weaker there. A different set of issues and problems influence the paths to social protection systems in lower middle income countries in the region.

The growth of social assistance has resulted in a change in the truncation of social protection systems in the region, but in the direction of a segmented or 'hyphenated' configuration of social protection components. With few exceptions, the growth of social assistance in the region has not been a case of an outward expansion of social insurance (as in the 'folk' view of the expansion of social protection in Europe). Instead it has worked through the introduction of a set of institutions with a different rationale, institutionalization, and financing. The spread of social assistance might have reduced the truncated nature of social protection, but this has been achieved by exacerbating segmentation. In most countries, social assistance is being institutionalized separately from social insurance, Ministries of Social Development as opposed to Ministries of Labour and Social Security. This suggests a long term cleavage. 
How will this situation evolve in the future? Current research and policy discussions have not lead to a settled view on this issue. The emerging orthodoxy argues for a stronger integration of social insurance and social assistance, and an urgent upgrade of labour market policies (CEPAL 2006; Ferreira and Robalino 2010; Levy 2008; Ribe et al. 2010). The outlook is different for lower and upper middle income countries in the region. In middle income countries the conditions for integrating well developed and longstanding social insurance institutions with emerging social assistance are hugely complex. ${ }^{17}$ In lower middle income countries, with underdeveloped and weak social insurance institutions, the expansion of social assistance as opposed to integration with social insurance is the urgent challenge for the medium term.

\section{Conclusions}

The main objective of this study was to trace the changes in social protection systems in the region and assess their distributional implications. It revisited the social insurance reforms of the 1990s, and the expansion of social assistance in the 2000s, discussing their implications for poverty and inequality and for the future of social protection in the region.

The development of social protection systems in the region relied upon social insurance as its main component, and paid very little attention to social assistance. At the turn of the century, social protection systems in Latin America could be described as truncated. The reforms of social insurance in the 1990s were supposed to reduce fiscal deficits and expand coverage, but managed neither of these two goals. The expansion of social assistance in the 2000s has contributed to fill in this gap. Large scale antipoverty programmes in upper middle income countries in the region provide a basic form of social protection to groups previously excluded from social insurance. In lower middle income countries, the expansion of social assistance has been more tentative and limited in scope. Social assistance is now a significant component of social protection in the region.

What are the distributional effects of these changes? The paper focused on the allocation of public subsidies to social insurance and assistance. In the context of Latin America, public subsidies to social insurance make a very small contribution to poverty reduction, and the impact on inequality is in the main regressive. Social assistance can be effective in reducing poverty, particularly where programmes prioritize the population in extreme poverty; but the size of the transfers relative to household income limits their impact on the poverty headcount rate. There is some evidence that social assistance can have a small, positive, impact on inequality.

It follows that a rebalancing of public subsidies away from social insurance and towards social assistance has the potential to improve welfare. The growth of social assistance shows this rebalancing is underway. The size of public subsidies to social insurance suggests the scope for this rebalancing is significant. Economic growth and an enhanced fiscal space have facilitated this rebalancing in the last decade.

17 This is a classic case of balancing the demands from welfarist approaches on the design and implementation of tax and transfer schemes with the demands from non-welfarist poverty eradication objectives (Akerlof 1978; Feldstein 1987). 
Have the changes in social protection been associated with the spread of left of centre governments? The social insurance reforms of the 1990s were part of a liberalization project, in many cases pushed through exceptional political conditions. The expansion of social assistance in the 2000s coincided with a shift in the region of the political centre of gravity to the left. However, but both left- and right-of-centre governments have supported it. The influence of left of centre political coalitions was associated with a rapid scaling up of social assistance. More generally, there is a stronger link between democratization and the expansion of social assistance, regardless of the politics of ruling parties. 18

Do these changes fit in with Latin America's open economies? There is little doubt that the stagnation of social insurance funds in Latin America is associated with the changes in the employment relationship brought about by the new conditions in liberalized labour markets. Social insurance works best for workers in long-term and stable employment. Multidimensional social assistance programmes are on paper better able to address 'new' vulnerabilities associated with irregular employment, and periods of low earnings and unemployment. Social assistance is better able to provide a floor to household consumption and investment in human development. In this sense, social assistance provides a better 'fit' with conditions in open economies with liberalized labour markets.

What do these changes tell us about the future of social protection in the region? There is little doubt that the growth in social assistance signals a reconfiguration of social protection systems in the region. The growing institutionalization of social assistance is a welcomed step forward in the transition towards comprehensive social protection systems in the region. The impact of the recent financial crisis on the economies of Latin America has underlined the urgency attached to developing and strengthening active labour market policies. There remains uncertainty over the evolution of the linkages between social insurance and social assistance. Innovative policies will be needed to progress on a greater integration of social insurance and assistance; but in lower middle income countries the expansion of social assistance constitutes a more urgent challenge.

18 Birdsall et al. (2011) draw a distinction between social democratic and populist left regimes, with most Central America and Andean countries falling in the latter group. Their analysis concludes that redistribution is less effective and sustainable in these countries. 


\section{References}

Akerlof, G.A. (1978). 'The Economics of “Tagging” as Applied to Optimal Tax, Welfare Programs, and Manpower Planning’. American Economic Review, 68(1): 819.

Arenas de Mesa, A. (2005). 'Fiscal and Institutional Considerations of Pension Reform: Lessons Learned from Chile’. In C. A. Crabbe (ed.), A Quarter Century of Pension Reform in Latin America and the Caribbean: Lessons Learned and Next Steps. Washington DC: Inter-American Development Bank.

Barreix, A., L. Villela, and J. Roca (2007). Fiscal Policy and Equity. Estimation of the Progressivity and Redistributive Capacity of Taxes and Social Public Expenditure in the Andean Region Report. Washington DC: Inter-American Development Bank.

Barrientos, A. (1998). Pension Reform in Latin America. Aldershot: Ashgate.

Barrientos, A. (2004). 'Latin America: Towards a Liberal-informal Welfare Regime’. In I. Gough, G. Wood, A. Barrientos, P. Bevan, P. David and G. Room (eds), Insecurity and Welfare Regimes in Asia, Africa and Latin America (pp. 121-168). Cambridge: Cambridge University Press.

Barrientos, A. (2009). 'Labour Markets and the (hyphenated) Welfare Regime in Latin America’. Economy and Society, 38(1): 87-108.

Barrientos, A. (2010). 'Protecting Capabilities, Eradicating Extreme Poverty: Chile Solidario and the Future of Social Protection'. Journal of Human Development and Capabilities, 11(4): 579-97.

Barrientos, A. (in press). 'Social Transfers and Growth. What do we Know? What do we Need to Find Out?'. World Development.

Barrientos, A., M. Niño-Zarazúa, and M. Maitrot (2010). Social Assistance in Developing Countries Database Version $5 . \quad$ Report http://papers.ssrn.com/sol3/papers.cfm?abstract_id=1672090. Manchester: Brooks World Poverty Institute.

Barrientos, A., and C. Santibañez (2009a). 'Social Policy for Poverty Reduction in Lower-income Countries in Latin America: Lessons and Challenges’. Social Policy and Administration, 43(4): 409-24.

Barrientos, A., and C. Santibañez (2009b). 'New Forms of Social Assistance and the Evolution of Social Protection in Latin America'. Journal of Latin American Studies, 41(1): 1-26.

Barros, R.P.D., M.D. Carvalho, and S. Franco (2007). O papel das trensferências públicas na queda recente da desigualdade de renda brasileira. In R. Paes de Barros, M. N. Foguel and G. Ulyssea (eds), Desigualdade de Renta no Brasil: Un anàlise de queda recente, 2: 41-86. Brasilia: IPEA.

Bertranou, F., E. Calvo, and E. Bertranou (2009). 'Is Latin America Retreating from Individual Retirement Accounts?’ Working Paper. Munich: Munich Personal RePEc Archive. 
Birdsall, N., N. Lustig, and D. McLeod (2011). 'Declining Inequality in Latin America: Some Economics, Some Politics’. Working Paper 1120. New Orleans: Tulane University.

Breceda, K., J. Rigolini, and J. Saavedra (2009). 'Latin America and the Social Contract: Patterns of Social Spending and Taxation'. Population and Development Review, 35(4): 721-48.

CEPAL (2006). La protección social de cara al futuro: Acceso, financiamiento y solidaridad. Santiago: CEPAL.

Cornia, G.A. (2010). 'Income Distribution under Latin America’s New Left Regimes'. Journal of Human Development and Capabilities, 11(2): 86-114.

Cubero, R., and I. Vladkova Hollar (2010). 'Equity and Fiscal Policy: The Income Distribution Effects of Taxation and Social Spending in Central America'. IMF Working Paper WP/10/112. Washington DC: IMF.

De Castro, J.A., J.A. Ribeiro, J.V. Chaves, B.D.C. Duarte, and H.B. Simões (2008). Gasto social e política macroeconômica: Trajetórias e tensões no periodo 1995-2005. Texto para Discussão 1324. Brasília: IPEA.

ECLAC (2009). ‘Social Panorama of Latin America 2009’. Santiago: ECLAC.

Feldstein, M. (1987). 'Should Social Security Benefits be Means Tested?'. Journal of Political Economy, 95(3): 468-84.

Ferreira, F.H.G., and D. Robalino (2010). 'Social protection in Latin America. Achievements and Limitations'. Policy Research Working Paper 5305. Washington DC: The World Bank.

Fiszbein, A. (2005). 'Beyond Truncated Welfare States: Quo Vadis Latin America?' Washington DC: The World Bank.

Gill, I.S., Packard, T., and Yermo, J. (2004). Keeping the Promise of Social Security in Latin America. Washington DC: Stanford University Press and the World Bank.

Goñi, E., J.H. López, and L. Servén (2008). 'Fiscal Redistribution and Income Inequality in Latin America'. Policy Research Working Paper WPS 4487. Washington DC: The World Bank.

Huber, E. (1996). 'Options for Social Policy in Latin America: Neoliberal versus Social Democratic Models’. In G. Esping-Andersen (ed.), Welfare States in Transition. National Adaptations in Global Economies. London: Sage.

ILO (2001). 'Panorama Laboral 2001'. Lima: International Labour Organisation.

Immervoll, H., H. Levy, J.R. Nogueira, C. O’Donoghue, and D.S.R. Bezerra (2006). 'The Impact of Brazil's Tax-benefit System on Inequality and Poverty'. Discussion Paper 2114. Bonn: IZA.

Jaccoud, L., P.D.E.-M. Hadjab, and J.R. Chaibub (2009). Assistência social e securança alimentar: Entre novas trajetórias, vehlas agendas e recentes desafíos (1988-2008). In Diretoría de Etudos e Políticas Sociais (Ed.), Políticas sociais: Acompanhamento e análise 17 (pp. 175-250). Brasilia: IPEA. 
Kay, S.J. (1999). 'Unexpected Privatizations. Politics and Social Security Reform in the Southern Cone’. Comparative Politics, 31(4): 403-22.

Levy, S. (2008). Good Intentions, Bad Outcomes. Social Policy, Informality and Economic Growth in Mexico. Washington DC: The Brookings Institution.

Lindert, K., and V. Vinscensini (2008). 'Social Policy, Perceptions and the Press: An Analysis of the Media's Treatment of Conditional Cash Transfers in Brazil'. Discussion Paper. Washington DC: The World Bank.

López-Calva, L.F., and N. Lustig (2010). 'Declining Inequality in Latin America: A Decade of Progress?' In Washington DC: Brookings Institution and UNDP.

Marcel, M., and W. Tapia (2010). Efectos de la crisis finaciera sobre las pensiones en America Latina. Documento de Trabajo IDB-WP-152. Washington DC: InterAmerican Development Bank.

Mesa-Lago, C. (1991). 'Social Security in Latin America and the Caribbean: A Comparative Assessment'. In E. Ahmad, J. Drèze, J. Hills and A. Sen (eds), Social Security in Developing Countries (pp. 357-94). Oxford: Clarendon Press.

Mesa-Lago, C. (2007). Reassembling Social Security. A Survey of Pensions and Healthcare Reforms in Latin America. Oxford: Oxford University Press.

Mesa-Lago, C. (2009). 'La Ley de reforma de la previsión social argentina: Antecedentes, razones, características y análisis de posibles resultados y riesgos'. Nueva Sociedad (219): 14-30.

Pinheiro, V.C. (2005). 'The Politics of Pension Reform in Brazil'. In C.A. Crabbe (ed.), A Quarter Century of Pension Reform in Latin America and the Caribbean. Lessons Learned and Next Steps (pp. 187-217). Washington DC: Inter-American Development Bank.

Pribble, J., E. Huber, and J.D. Stephens (2005). 'The Politics of Poverty in Latin America and the Caribbean'. Mimeo. Washington DC: American Political Science Association.

Ribe, H., D.A., Robalino, and I. Walker (2010). Achieving Effective Social Protection for all in Latin America and the Caribbean. From Right to Reality. Washington DC: The World Bank.

Saboia, J. (2009). 'Efeitos do Salário Mínimo sobre a Distribuição de Renda no Brasil no Período 1995/2005 - Resultados de Simulações’. Economía, 11(1): 51-77.

Schwarzer, H., and A.C. Querino (2002). 'Non-contributory Pensions in Brazil: The Impact on Poverty Reduction’. ESS Paper 11. Geneva: Social Security Policy and Development Branch, ILO.

Scott, J. (2005). 'Seguridad social y desigualdad en México: De la polarización a la universalidad’. Bienestar y Política Social, 1(1): 59-82.

Silveira, F.G. (2008). Tributacao, prêvidencia e assistência social. Mimeo. Brasilia: Tesouro Nacional.

Skoufias, E. (2005). 'Progresa and its Impacts on the Welfare of Rural Households in Mexico’. Washington: International Food Policy Research Institute 
Skoufias, E., K. Lindert, and J. Shapiro (2010). 'Globalization and the Role of Public Transfers in Redistributing Income in Latin America and the Caribbean'. World Development, 38(6): 895-907.

Soares, F.V., and T.F.D. Britto (2007). 'Confronting Capacity Constraints on Conditional Cash Transfer Programmes in Latin America’. Working Paper 38. Brasilia: International Poverty Centre.

Soares, F.V., S. Soares, M. Medeiros, and R.G. Osório (2006). 'Cash Transfer Programmes in Brazil: Impacts on Inequality and Poverty'. Brasilia: International Poverty Centre.

Soares, S., P.H.F. de Souza, R.G. Osório, and F.G. Silveira (2010). Os impactos do benefício do Programa Bolsa Família sobre a desigualdade e a pobreza. In J.A. de Castro and L. Modesto (eds), Bolsa Família 2003-2010: avanços e desafios (Vol. 1). Brasilia: IPEA.

Soares, S., R. Guerreiro Osório, F. Veras Soares, M. Medeiros, and E. Zepeda (2007). 'Conditional Cash Transfers in Brazil, Chile and Mexico: Impacts upon Inequality'. In International Poverty Centre Working Paper. Brasilia: International Poverty Centre.

World Bank (2010). 'Did Latin America Learn to Shield its Poor from Economic Shocks?' Report. Washington DC: The World Bank. 